\title{
Tuberculous splenic abscess in the immunocompetent host: a report and review of literature
}

\author{
Satyajeet Sahoo${ }^{1}$, Suprava Naik², Baijayantimala Mishra ${ }^{3}$, Gopal Durgeshwar ${ }^{1}$, Manoj Kumar Panigrahi', \\ Sourin Bhuniya ${ }^{1}$ \\ ${ }^{1}$ Department of Pulmonary Medicine and Critical Care, All India Institute of Medical Sciences, Bhubaneswar; \\ ${ }^{2}$ Department of Radiodiagnosis, All India Institute of Medical Sciences, Bhubaneswar; ${ }^{3}$ Department of Microbiology, \\ All India Institute of Medical Sciences, Bhubaneswar, India
}

\begin{abstract}
Tuberculous splenic abscess is rare, particularly in immunocompetent patients. Diagnostic difficulties usually arise in patients with tuberculous splenic abscess because of its non-specific presentation. We report an elderly male who presented with cough and fever and had pulmonary infiltrates suspicious of tuberculosis. Bronchoalveolar lavage microbiology including XpertMTB/Rif
\end{abstract}

Correspondence: Dr. Sourin Bhuniya, Department of Pulmonary medicine and Critical care, All India Institute of Medical Sciences, Room no. 146, OPD block (1st floor), Bhubaneswar 751019, India.

Mobile: +91.9438884284. E-mail: sbhuniya@hotmail.com

Key words: Splenic tuberculosis; splenic abscess; disseminated tuberculosis; immunocompetent.

Contributions: SB, MKP, study concept, provision of personnel, environmental support and tools/instruments for the study; SB, methodology planning, study supervision; BM, SN, SS, SN, data collection and/or processing. All author gave substantial contribution to data analysis and interpretation, literature review, critical review of the manuscript. All the authors have read and approved the final version of the manuscript and agreed to be accountable for all aspects of the work.

Conflict of interest: The Authors declare no conflict of interest.

Availability of data and materials: All data generated or analyzed during this study are included in this published article.

Ethics approval and consent to participate: All procedures performed in studies involving human participants were in accordance with the ethical standards of the Institutional Research Committee and with the 1964 Helsinki declaration and its latest amendment.

Received for publication: 10 September 2019.

Accepted for publication: 19 January 2020.

${ }^{\circ}$ Copyright: the Author(s), 2020

Licensee PAGEPress, Italy

Monaldi Archives for Chest Disease 2020; 90:1167

doi: 10.4081/monaldi.2020.1167

This article is distributed under the terms of the Creative Commons Attribution Noncommercial License (by-nc 4.0) which permits any noncommercial use, distribution, and reproduction in any medium, provided the original author(s) and source are credited. assay was non-contributory. Contrast enhanced computed tomography scan of abdomen revealed multiple non-enhancing lesions in the spleen. Ultrasound guided splenic aspirate revealed pus that was positive for Mycobacterium tuberculosis in XpertMTB/Rif assay confirming the diagnosis of tuberculosis.

\section{Introduction}

Splenic tuberculosis with abscess formation is an uncommon manifestation and occurs primarily in immunocompromised patient. Due to its indistinct clinical features splenic tuberculosis has always remained a diagnostic challenge. We report a case of fever of unknown origin whose bronchoalveolar lavage failed to give a diagnosis even though his radiological features were suggestive of pulmonary tuberculosis. However, the diagnosis was established by XpertMTB/Rif test of the pus from splenic abscess which detected Mycobacterium tuberculosis (MTB). We also did a mini-review of the recent published literature on tuberculous involvement of spleen in immunocompetent host.

\section{Case Report}

An 81-year-old male carpenter presented with cough without any expectoration or haemoptysis for last two months. For the past 25 days he had intermittent fever and exertional breathlessness. There was no history of wheeze, chest pain, haematuria, epistaxis, vomiting, headache, joint pain or skin rash. His appetite had reduced and had lost $8 \mathrm{~kg}$ in the last two months. He was non-diabetic, seronegative for Human Immunodeficiency Virus (HIV) and denied any history of pulmonary tuberculosis in the past. Patient had taken multiple courses of antibiotics without any improvement in symptoms. On clinical examination, he was conscious, oriented but looked emaciated. Respiratory rate was 26/min with bilateral normal vesicular breath sounds. No abdominal organs were palpable on clinical examination. Initial laboratory investigations revealed microcytic hypochromic anaemia (haemoglobin - $10 \mathrm{~g} / \mathrm{dl}$ ), elevated white blood cell (14,560/cumm) count with neutrophilia and a raised erythrocyte sedimentation rate (ESR). Platelet counts, coagulation profile, renal and liver function tests were normal. Chest radiograph showed ill-defined opacities in right upper and middle lung zones (Figure 1). Computed tomography (CT) scan of thorax showed cavitary lesion in right upper lobe, minimal fibrosis and multiple tiny nodular opacities in bilateral lung fields some of 
them showing tree in bud appearance (Figure 2). Induced sputum analysis by XpertMTB/Rif assay was negative. No endobronchial lesions were found on bronchoscopy and bronchoalveolar lavage (BAL) was sent for microbiological and cytological tests. After a week during his follow up visit with BAL reports the patient's general condition had further deteriorated. BAL was negative for acid fast bacilli (AFB) stain and CBNAAT for MTB. Bacterial and fungal cultures of BAL showed no growth. He was admitted for further evaluation. Repeat blood counts, renal and liver function tests were within normal limits. Blood and urine cultures were sterile.

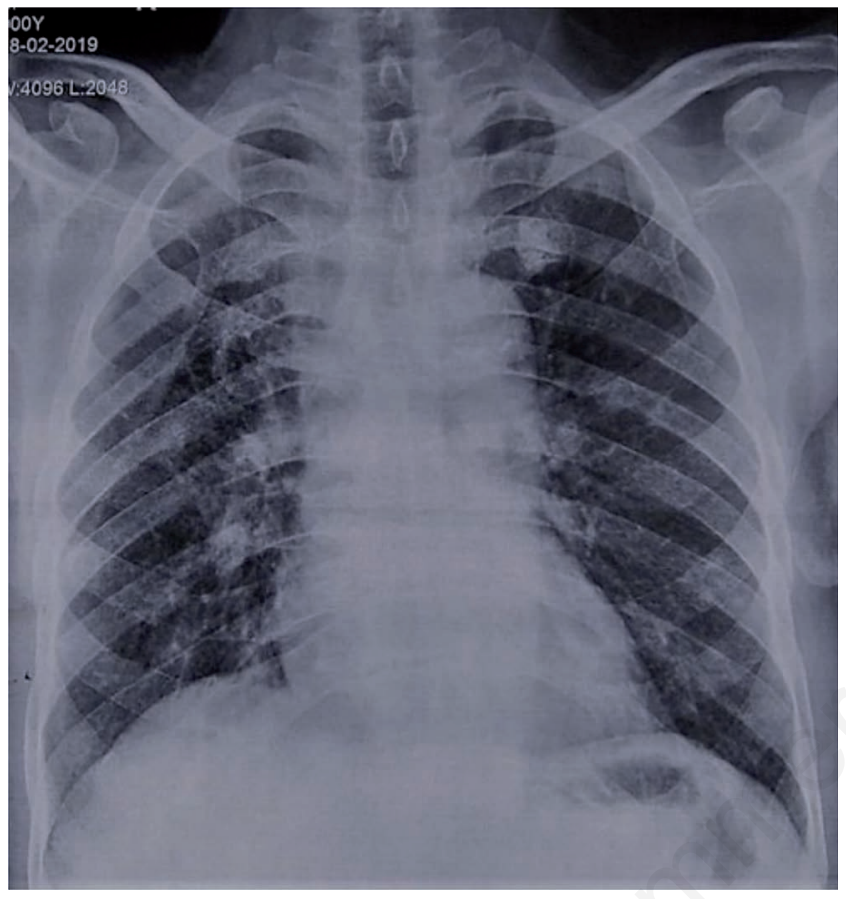

Figure 1. Chest radiograph shows ill-defined opacity in right upper and middle lung zones.

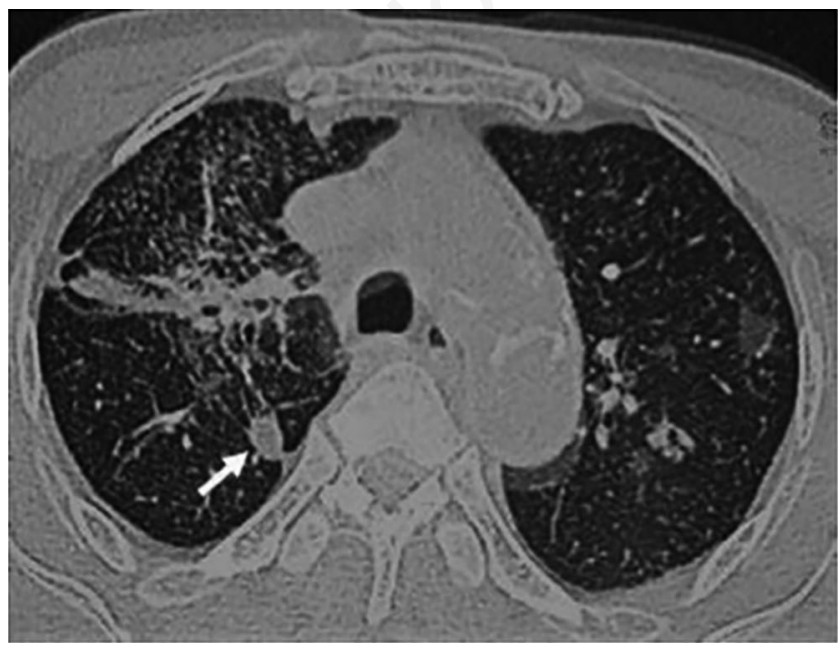

Figure 2. Axial CT scan of thorax (lung window) shows cavitating lesion in right upper lobe, nodule (arrow), minimal fibrosis and multiple tiny nodular opacities in bilateral lung fields.
Echocardiography was unremarkable. Subsequently, work up for auto-immune diseases and vasculitis panel was also negative. In view of persisting fever, contrast enhanced CT thorax and abdomen was done, that showed bilateral pleural effusion in addition to widespread nodules in bilateral lung fields (Figure 3). Multiple well defined non-enhancing hypodense lesions were present in splenic parenchyma suggestive of abscesses (Figure 4). Under ultrasonographic guidance around $2 \mathrm{ml}$ of thick pus was aspirated from the splenic abscess. CBNAAT was positive (rifampicin sensitive) for MTB in the aspirated pus. Cultures ruled out the presence of any

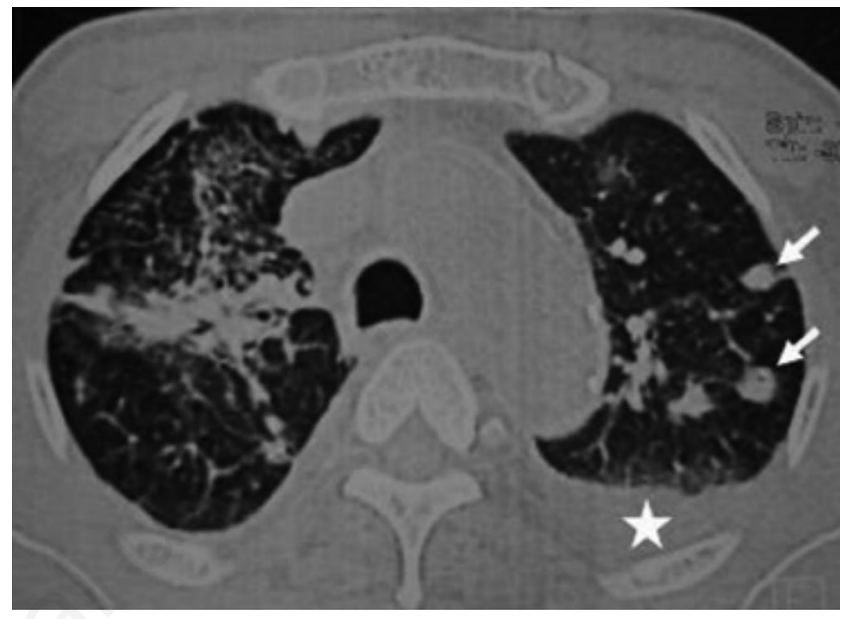

Figure 3. Axial CT scan of thorax done a month later at same level (lung window) shows pleural effusion (star) and increased nodular lesions (arrows) in both lung fields.

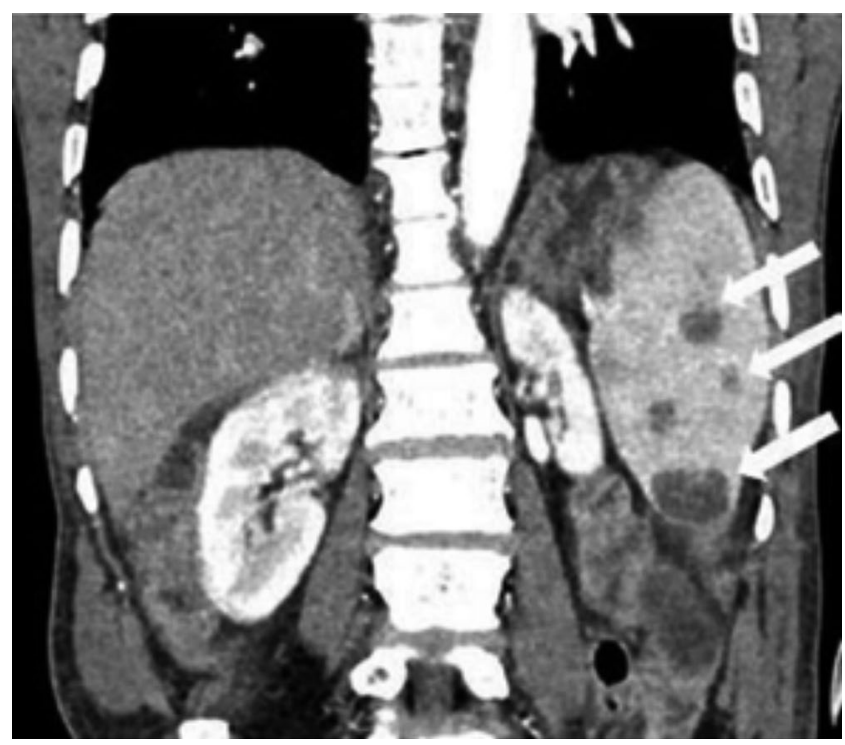

Figure 4. CECT of abdomen (coronal reformatted image) shows multiple non-enhancing hypodense lesions within splenic parenchyma (white arrows). 
other bacterial or fungal organism in aspirated pus. Anti-tubercular therapy (ATT) with four drugs regimen was started and patient became afebrile on $15^{\text {th }}$ day of initiation of ATT.

\section{Discussion}

The common modality of splenic abscesses formation is haematogenous dissemination to the spleen from an infective focus or usually associated with disseminated infection. The burden of extra-pulmonary tuberculosis (EPTB) is high, ranging from 15$20 \%$ in HIV-negative patients to $40-50 \%$ in patients with HIV pos- itivity. EPTB distribution includes lymph nodes, pleural space, bones and joints, genitourinary, brain and abdomen in decreasing incidence. Abdominal TB which contributes to a mere 3\% of all EPTB encompasses gastrointestinal tract, peritoneum, omentum, mesentery, regional lymph nodes and solid organs like liver, spleen and pancreas [1]. Tubercular involvement of liver, pancreas and spleen usually occurs in miliary or disseminated tuberculosis and commonly affect immunocompromised individuals. Isolated abdominal solid organ TB is rare in immunocompetent individuals. The incidence of splenic TB is $0.14-0.7 \%$ as per autopsy-based studies [2]. Clinical manifestations are non-specific like anorexia, fever, malaise, weight loss, night sweats, melena, pain abdomen and jaundice. Splenic TB can present as splenomegaly, hyper-

Table 1. Summary of evidence on splenic tuberculosis.

$\begin{array}{llll}\text { S1 } & \text { Year } & \text { Author } & \text { Journal } \\ 1 & 2019 & \text { Hashmi et al. } & \begin{array}{l}\text { Journal of Ayub Medical } \\ \text { College, Abbottabad }\end{array}\end{array}$
Title Main findings Comments College, Abbottabad
Splenic abscess as a complication of extrapulmonary tuberculosis
85/F with fever, cough, pain abdomen had multiple bilateral small opacities on chest radiograph.

Laparotomy revealed a ruptured splenic abscess.

2018 Dhibar et al. Oman Medical Journal

Isolated cold splenic abscesses in an immunocompetent individual

\begin{tabular}{lll}
\hline $32018 \quad$ Sanke et al. & $\begin{array}{l}\text { International Journal of } \\
\text { Dermatology }\end{array}$
\end{tabular}

Metastatic tubercular gummas and splenic tuberculoma secondary to tubercular lymphadenitis in animmunocompetent female

$42018 \quad$ Dawani et al. Tropical Doctor

Diagnosing isolated hepatosplenic tuberculosis in an immunocompetent patient: a case report

Splenic tuberculosis in an immunocompetent patient can be managed conservatively: a case report

\begin{tabular}{lll}
\hline $52018 \quad$ Kumar et al. $\quad$ Gastroenterology Report & Splenic tuberculosis in \\
& \\
& an immunocompetent \\
& patient can be managed \\
& conservatively: a case \\
& report
\end{tabular}

62017 Khadka et al. Case Reports in Isolated splenic cold Gastrointestinal Medicine abscesses with peri-splenic extension: treated successfully without splenectomy

72017 Divyashree et al. The Permanente Journal Splenic abscess in immunocompetent patients managed primarily without splenectomy: a series of 7 cases in spleen. lesion in splenic parenchyma without significant vascularity suggestive of tuberculoma. nodes. splenomegaly. CECT of the abdomen revealed a hypodense lesion in the spleen with minimal left-sided pleural effusion.
22/M with intermittent fever and left chest pain. CT showed peri-splenic hypodense collections and multiple splenic abscesses.

Of 7 cases with splenic abscess only one was of tubercular aetiology who was a 20/M with pain upper abdomen, and fever.

CT showed mild splenomegaly with a single abscess.

30/M with pain abdomen Xpert MTB test and microbiology and non-tender splenomegaly smears of aspirate from the spleen had multiple hypoechoic confirmed Mycobacterium areas with anechoic content tuberculosis.

31/F presented with Pus discharge from skin ulcer was multiple painful nodular sent for CB NAAT which was abscesses all over her body. positive for mycobacterium USG showed hypoechoic tuberculosis.

32/M with fever, weight loss Biopsy of the hepatic lesions revealed and splenomegaly. caseous necrosis suggestive of CT showed multiple lesions tuberculosis. However AFB smear throughout the liver, enlarged and PCR assay of aspirate from liver spleen and mesenteric lesions were negative for Mycobacterium tuberculosis.

51/M with fever, pain left A diagnosis of splenic tuberculosis
upper abdomen and tender was made by the findings of a

USG-guided aspirated pus was negative for AFB staining; however, PCR for MTB was positive.

\section{CT-guided aspiration was positive for} acid-fast bacilli, and cultures yielded Mycobacterium tuberculosis. 
splenism, solitary splenic lesion or splenic abscess. Multiple abscesses in splenic parenchyma is usually seen in patients with HIV infection but is a rare entity in patients with preserved immunity [3-5]. A non-systematic review of the evidence published between 2000 and 2019 was done, searching from the MEDLINE database, using the key words, 'splenic tuberculosis' and 'immunocompetent'. Search results were filtered to include only the articles in English language and those involving adult patients. With this methodology, we found 31 articles with tuberculous involvement of spleen, of which 23 had attempted some kind of invasive intervention on spleen such as fine needle aspiration, biopsy and splenectomy (Tables 1-3). Of the 23 articles only five had detected MTB by CBNAAT in the splenic sample (Table 2).
Besides, there were nine published articles where the diagnosis of tuberculosis was established by samples from sites other than spleen (Table 3). Study done by Dixit et al. over a period of 3 years in an Indian hospital found only 16 patients $(0.01 \%)$ with splenic involvement from a total of 9205 TB patients and were able to identify a cause for immunodeficiency in only 9 of those 16 patients ( 8 with HIV infection and 1 with myelodysplastic syndrome). Ten of those 16 patients in their study had pulmonary involvement too [6]. In a retrospective study done by Chien et al., 590 cases with active TB were identified over a period of 13 years who received care at the Saint Michael's Hospital TB Clinic in Canada, 24 had abdominal TB. Surprisingly none of them had splenic involvement [7]. Haematogenous infection, contiguous

Table 1. Continued from previous page.

\begin{tabular}{|c|c|c|c|c|c|}
\hline Sl & Year & Author & Journal & Title & Main findings \\
\hline 8 & 2017 & Wangai et al. & BMC Research Notes & $\begin{array}{l}\text { Isolated splenic } \\
\text { tuberculosiswith } \\
\text { subsequent paradoxical } \\
\text { deterioration: a case } \\
\text { report }\end{array}$ & $\begin{array}{l}\text { 26/M with PUO. CT scan } \\
\text { showed enlarged spleen } \\
\text { with multiple hypodense } \\
\text { nodules suggestive of } \\
\text { multiple splenic } \\
\text { microabscesses. }\end{array}$ \\
\hline
\end{tabular}

\section{Comments}

Histopathological study of the splenic biopsy specimen revealed extensive multiple granulomas mainly necrotising. ZN stain of the biopsy processed specimen revealed acid-fastbacilli, confirmed by GeneXpert MTB/RIF which yielded MTB sensitive to rifampicin.

\begin{tabular}{lll}
\hline $92017 \quad$ Rao et al. & BJR Case Reports & $\begin{array}{l}\text { Isolated splenic } \\
\text { tuberculosis detected } \\
\text { only on FDG-PET }\end{array}$
\end{tabular}

17/F with PUO had normal chest radiograph CT abdomen was normal. MRI abdomen, did not show any nodules in the spleen.

\begin{tabular}{lll}
\hline $10 \quad 2016 \quad$ Nasa et al. & Indian Journal of & Isolated splenic \\
& Tuberculosis & tuberculosis diagnosed \\
& & by endoscopic \\
& & ultrasound-guided fine \\
& & needle aspiration
\end{tabular}

\begin{tabular}{lll}
\hline $112016 \quad$ Diallo et al. $\quad$ BMC Research Notes & Hepatosplenic \\
& & tuberculosis simulating \\
& secondary malignant \\
& lesions with cholangitis
\end{tabular}

\begin{tabular}{llll}
\hline 12 & 2016 & Lin et al. & $\begin{array}{l}\text { World Journal of } \\
\text { Surgical Oncology }\end{array}$ \\
\hline 13 & 2015 & Amraoui et al. & $\begin{array}{l}\text { International Journal } \\
\text { of Mycobacteriology }\end{array}$
\end{tabular}

Solitary splenic $\quad$ 64/F with abdominal tuberculosis: a case reportdiscomfort and nausea. and review of the literature

48/F presented with persistent low-grade fever and weight loss.

CT abdomen revealed multiple hypodense lesions in spleen.

48/F with febrile jaundice had multiple in liver and spleen, pulmonary calcifications, mediastinal and abdominal lymph nodes on CT scan.

18 FDG-PET-CT scan demonstrated multiple focal areas of high FDG uptake within the spleen which on biopsy revealed necrotizing granulomatous lesions suggestive of TB.

Endoscopic ultrasound-guided fine needle aspiration of splenic lesion revealed granulomatous inflammation. hypoechoic lesion.

Cutaneous tuberculosis Out of 7 cases with revealing multifocal tuberculosis in immunocompetent patients multifocal tuberculosis only 1 had splenic involvement. Skin biopsy showed giant epithelioid cell granuloma with caseation.

\begin{tabular}{|c|c|c|c|}
\hline $14 \quad 2015$ & Lee et al. & $\begin{array}{l}\text { The Korean Journal } \\
\text { of Gastroenterology }\end{array}$ & $\begin{array}{l}\text { Splenic tuberculosis } \\
\text { forming a gastro-splenic } \\
\text { fistula }\end{array}$ \\
\hline
\end{tabular}
61/M with cough and abdominal discomfort had consolidations with multi-focal hypodense lesions in the spleen.

$152014 \quad$ Chakradhar et al. BMJ Case Reports $\quad \begin{aligned} & \text { A rare presentation of } \\ & \text { splenic tuberculosis } \\ & \text { with a pseudocyst }\end{aligned}$

24/F with pain in upper abdomen, fever and a palpable abdominal mass.

\author{
Liver biopsy showed epithelioid and \\ giant cell granulomas without \\ caseous necrosis. A multifocal \\ tuberculosis was diagnosed and patient \\ was started with anti-tubercular \\ therapy. \\ Splenectomy specimen showed \\ granulomatous inflammation with \\ large inflammatory necrosis and \\ caseation necrosis. \\ Article does not mention separately \\ how the splenic involvement was \\ diagnosed and confirmed.

A fistula tract between the stomach
and spleen was seen on endoscopy.
ZN stain for AFB and PCR for
tuberculosis were negative. Biopsy
showed a well-defined granuloma
with caseous necrosis.
Total splenectomy was carried out.
Histopathology was consistent with
splenic TB.

To be continued on next page. 
infection, haemoglobinopathies, HIV infection, chemotherapy, and trauma are the various mechanisms of splenic abscess formation. The red pulp of the spleen is relatively devoid of phagocytic activity and helps the entrapped, slow-growing mycobacteria to escape from the reticuloendothelial system of spleen explaining for the tubercular aetiology of splenic abscess. On CT, tubercular splenic abscess is characterised by solitary or multiple hypodense nodular areas which are usually small $(<2 \mathrm{~cm})$, ill-defined with mild contrast-enhancement [8]. Radiologically, splenic tuberculosis is classified as micronodular or macronodular, depending on whether it is smaller or larger than $10 \mathrm{~mm}$, respectively [9]. The former is more common and usually seen in disseminated TB whereas the later one is rare and could manifest as a single abscess or multiple large nodules or multiple abscesses. Our patient had pulmonary involvement as well but the bronchoalveolar lavage failed to demonstrate Mycobacterium tuberculosis in XpertMTB/Rif assay.
Studies have shown that in sputum smear negative patients with clinico-radiological features of pulmonary tuberculosis, XpertMTB/Rif has good sensitivity for diagnosis in BAL and it may even obviate the need for transbronchial lung biopsy $[10,11]$. Our patient never experienced any abdominal symptoms in his entire course of illness even though he had multiple splenic abscesses. However, the aspirate from splenic abscess clinched the diagnosis of tuberculosis by CBNAAT.

Therefore, evaluation for extrapulmonary involvement of tuberculosis is crucial in establishing the diagnosis in patients with strong suspicion of pulmonary tuberculosis but non-contributory mycobacterial tests from pulmonary samples. In such cases, even a small amount of diagnostic sample, if can be obtained from the involved organ, may be very useful to clinch the diagnosis. Last but not the least, splenic abscess even in immunocompetent individuals, should raise the suspicion of tubercular aetiology.

Table 1. Continued from previous page.

\begin{tabular}{|c|c|c|c|c|c|c|}
\hline SI & Year & Author & Journal & Title & Main findings & Comments \\
\hline 16 & 2014 & Jain et al. & $\begin{array}{l}\text { Oxford Medical } \\
\text { Case Reports }\end{array}$ & $\begin{array}{l}\text { Disseminated } \\
\text { tuberculosis causing } \\
\text { isolated splenic vein } \\
\text { thrombosis and multiple } \\
\text { splenic abscesses }\end{array}$ & $\begin{array}{l}\text { 16/F with fever, dry cough, } \\
\text { jaundice, chronic diarrhoea, } \\
\text { amenorrhea and weight loss. } \\
\text { CT chest revealed mediastinal } \\
\text { lymph nodes and } \\
\text { consolidation. CT abdomen } \\
\text { revealed multiple hypodense } \\
\text { lesions in the spleen and } \\
\text { splenic vein thrombosis. }\end{array}$ & $\begin{array}{l}\text { Bone marrow culture was positive for } \\
\text { MTB. Pleural fluid PCR study was } \\
\text { also positive for M. tuberculosis. }\end{array}$ \\
\hline 17 & 2014 & Mandal et al. & BMJ Case Reports & $\begin{array}{l}\text { Isolated splenic } \\
\text { tuberculosis in an } \\
\text { immunocompetent } \\
\text { patient }\end{array}$ & $\begin{array}{l}\text { 20/F with fever, weakness } \\
\text { and weight loss had } \\
\text { splenomegaly and hypoechoic } \\
\text { areas in splenic parenchyma. }\end{array}$ & $\begin{array}{l}\text { Few AFBs were detected in the CT } \\
\text { guided aspirate. }\end{array}$ \\
\hline 18 & 2013 & Mishra et al. & Indian Journal of Surgery & $\begin{array}{l}\text { Isolated tuberculosis } \\
\text { of the spleen: A case } \\
\text { report and review of } \\
\text { literature }\end{array}$ & $\begin{array}{l}\text { 28/M with left abdominal } \\
\text { discomfort. Enlarged spleen } \\
\text { with cystic lesion containing } \\
\text { pus. }\end{array}$ & $\begin{array}{l}\text { Splenectomy was performed. The cut } \\
\text { section of the lesion showed } \\
\text { caseating necrosis of the spleen. }\end{array}$ \\
\hline 19 & 2013 & Yeo et al. & $\begin{array}{l}\text { Tuberculosis and } \\
\text { Respiratory Diseases }\end{array}$ & $\begin{array}{l}\text { Spontaneous splenic } \\
\text { rupture as a paradoxical } \\
\text { reaction during treatment } \\
\text { for splenic tuberculosis }\end{array}$ & $\begin{array}{l}\text { 33/F with high fever and } \\
\text { abdominal pain had } \\
\text { multiple low-density } \\
\text { lesions in the spleen and } \\
\text { enlarged mesenteric lymph } \\
\text { nodes. }\end{array}$ & $\begin{array}{l}\text { USG guided splenic biopsy revealed } \\
\text { inflammatory cells with focal } \\
\text { necrosis, AFB staining and TB-PCR } \\
\text { were negative. Based on clinical and } \\
\text { radiological findings anti-tubercular } \\
\text { drugs were started. }\end{array}$ \\
\hline 20 & 2013 & Basa et al. & $\begin{array}{l}\text { International Journal } \\
\text { of Surgery Case Reports }\end{array}$ & $\begin{array}{l}\text { A case of isolated splenic } \\
\text { tuberculosis }\end{array}$ & $\begin{array}{l}\text { 27/M with presented with } \\
\text { epistaxis. PET scan showed } \\
\text { splenomegaly with } \\
\text { hypermetabolic FDG activity. }\end{array}$ & $\begin{array}{l}\text { Splenectomy was performed in view } \\
\text { of dropping platelet count.The entire } \\
\text { spleen wasreplaced by caseating } \\
\text { granulomas and necrotizing-type } \\
\text { granulomatous inflammation. } \\
\text { Mycobacterium tuberculosiswere } \\
\text { seen by AFB stain. }\end{array}$ \\
\hline 21 & 2012 & Lonkar et al. & $\begin{array}{l}\text { Annals of Medical and } \\
\text { Health Sciences Research }\end{array}$ & $\begin{array}{l}\text { Splenic tuberculosis } \\
\text { presenting as ascites in } \\
\text { immunocompetent } \\
\text { patient }\end{array}$ & $\begin{array}{l}\text { 60/M with pain abdomen, } \\
\text { vomiting and distended } \\
\text { abdomen. CT guided fine } \\
\text { needle aspiration from } \\
\text { splenic lesions showed } \\
\text { granulomas with area of } \\
\text { caseation favouring } \\
\text { diagnosis of tuberculosis }\end{array}$ & $\begin{array}{l}\text { Culture and polymerase chain } \\
\text { reaction-based confirmation could } \\
\text { not be contemplated due to } \\
\text { inadequacy of sample. }\end{array}$ \\
\hline 22 & 2012 & Park et al. & $\begin{array}{l}\text { Soonchunhyang } \\
\text { Medical Science }\end{array}$ & $\begin{array}{l}\text { Primary hepatosplenic } \\
\text { tuberculosis in an } \\
\text { immunocompetent adult } \\
\text { and domestic literature } \\
\text { review }\end{array}$ & $\begin{array}{l}\text { 25/M with intermittent } \\
\text { fever and night sweats. } \\
\text { CT scan showed } \\
\text { hepatosplenomegaly and } \\
\text { multiple microabscesses in } \\
\text { the spleen. }\end{array}$ & $\begin{array}{l}\text { TB-PCR, ZN stain, liquid and solid } \\
\text { culture for MTB in the liver biopsy } \\
\text { specimen were negative. } \\
\text { Histopathology of the liver } \\
\text { specimens revealed caseous necrosis } \\
\text { based on which tuberculosis was } \\
\text { diagnosed. }\end{array}$ \\
\hline
\end{tabular}


Table 1. Continued from previous page.

\begin{tabular}{|c|c|c|c|c|c|c|}
\hline SI & Year & Author & Journal & Title & Main findings & Comments \\
\hline 23 & 2012 & Kim et al. & $\begin{array}{l}\text { Journal of Clinical } \\
\text { Medicine Research }\end{array}$ & $\begin{array}{l}\text { Primary tuberculous } \\
\text { abscess of the spleen } \\
\text { in an immunocompetent } \\
\text { patient diagnosed by } \\
\text { biochemical markers } \\
\text { and radiologic findings }\end{array}$ & $\begin{array}{l}\text { 55/F with abdominal } \\
\text { distension, fever and weight } \\
\text { loss. CT scan revealed } \\
\text { splenomegaly with multiple } \\
\text { well-defined lesions and } \\
\text { ascites. }\end{array}$ & $\begin{array}{l}\text { ADA of ascitic fluid was } 76.9 \mathrm{IU} / \mathrm{L} \text {. } \\
\text { Interferon-gamma release assay was } \\
\text { positive and thus patient was started } \\
\text { on anti-tubercular treatment. }\end{array}$ \\
\hline 24 & 2012 & Ray et al. & $\begin{array}{l}\text { Indian Journal } \\
\text { of Medical Microbiology }\end{array}$ & $\begin{array}{l}\text { Isolated tubercular } \\
\text { splenic abscess: Can we } \\
\text { defer splenectomy? Our } \\
\text { single experience with } \\
\text { anti-tuberculous therapy } \\
\text { alone }\end{array}$ & $\begin{array}{l}\text { 35/F with fever, malaise, } \\
\text { weight loss and night sweats. } \\
\text { CT of the abdomen showed } \\
\text { multiple well-defined } \\
\text { hypodense lesions in spleen. }\end{array}$ & $\begin{array}{l}\text { Splenic lesion biopsy showed } \\
\text { granulomas with areas of caseation. } \\
\text { Few acid-fast bacilli on ZN staining. } \\
\text { Culture and PCR based } \\
\text { confirmation could not be done due } \\
\text { to less sample. }\end{array}$ \\
\hline 25 & 2011 & Rojo et al. & $\begin{array}{l}\text { Diagnostic Microbiology } \\
\text { and Infectious Disease }\end{array}$ & $\begin{array}{l}\text { Multidrug-resistant } \\
\text { tuberculosis presenting } \\
\text { as a solitary splenic } \\
\text { mass in an } \\
\text { immunocompetent } \\
\text { patient }\end{array}$ & $\begin{array}{l}\text { 60/F with anemia, asthenia } \\
\text { and arthralgia. CT revealed } \\
\text { a 10-cm spleen mass. } \\
\text { PET revealed an abnormal, } \\
\text { hypermetabolic activity } \\
\text { within an enlarged spleen. } \\
\text { Splenectomy was carried } \\
\text { out for a definitive diagnosis. }\end{array}$ & $\begin{array}{l}\text { Histopathology showed multiple } \\
\text { granulomas with large caseation } \\
\text { areas. No acid-fast bacilli were } \\
\text { found. Mycobacterium tuberculosis } \\
\text { DNA was detected in TB PCR } \\
\text { analysis of sample. Genotype } \\
\text { MTBDR plus kit detected rifampicin } \\
\text { and isoniazid (high and low level) } \\
\text { genes. }\end{array}$ \\
\hline 26 & 2010 & Pottakkat et al. & Gut and Liver & $\begin{array}{l}\text { Tuberculosis of the } \\
\text { spleen as a cause of } \\
\text { fever of unknown origin } \\
\text { and splenomegaly }\end{array}$ & $\begin{array}{l}339 \text { splenectomies } \\
\text { performed between January } \\
1989 \text { and December } 2008 \\
\text { for indications other than } \\
\text { trauma. }\end{array}$ & $\begin{array}{l}\text { Histopathologic analysis of the spleen } \\
\text { revealed tuberculosis in } 8 \text { patients. } \\
\text { All } 8 \text { patients were referred for } \\
\text { splenectomy due to fever of } \\
\text { unknown origin. }\end{array}$ \\
\hline 27 & 2010 & Udgaonkar et al. & $\begin{array}{l}\text { Indian Journal } \\
\text { of Medical Microbiology }\end{array}$ & $\begin{array}{l}\text { Asymptomatic, isolated } \\
\text { tubercular splenic } \\
\text { abscess, in an } \\
\text { immunocompetent } \\
\text { person }\end{array}$ & $\begin{array}{l}\text { 38/F with complaints of } \\
\text { vaginal vault prolapse. } \\
\text { Preoperative USG abdomen } \\
\text { revealed hypoechoic areas } \\
\text { in spleen. }\end{array}$ & $\begin{array}{l}\text { USG guided FNAC of splenic lesion } \\
\text { yielded pus. ZN stain of the pus } \\
\text { showed presence of a few acid fast } \\
\text { bacilli. Mycobacterium tuberculosis } \\
\text { grew on Lowenstein Jensen medium } \\
\text { after six weeks of incubation. }\end{array}$ \\
\hline 28 & 2009 & Raul & Indian Journal of Surgery & $\begin{array}{l}\text { Tubercular splenic } \\
\text { abscess in } \\
\text { immunocompetent } \\
\text { patients: a rare entity }\end{array}$ & $\begin{array}{l}\text { Case 1: 50/F with fever and } \\
\text { pain abdomen had } \\
\text { splenomegaly with large } \\
\text { cystic necrotic areas within } \\
\text { the spleen. Case } 2: 22 / \mathrm{M} \\
\text { with dull aching pain } \\
\text { abdomen, splenomegaly } \\
\text { along with multiple } \\
\text { abscesses with areas of } \\
\text { infarcts. }\end{array}$ & $\begin{array}{l}\text { Case 1: Splenectomy was performed. } \\
\text { Biopsy reported as tubercular abscess } \\
\text { of spleen. The pus sent for AFB stain } \\
\text { was positive.Case 2: Splenectomy } \\
\text { was performed. Biopsy was reported } \\
\text { as tuberculosis of spleen. }\end{array}$ \\
\hline 29 & 2009 & Fooladi et al. & $\begin{array}{l}\text { International Journal } \\
\text { of Infectious Diseases }\end{array}$ & $\begin{array}{l}\text { Splenic tuberculosis: } \\
\text { a case report }\end{array}$ & $\begin{array}{l}\text { 47/M with pain left } \\
\text { hypochondrium and tender } \\
\text { splenomegaly. CT scan } \\
\text { showed diffuse lesions and } \\
\text { multiple micronodules in the } \\
\text { spleen. Splenectomy was } \\
\text { carried out. }\end{array}$ & $\begin{array}{l}\text { Large areas of caseation, multiple } \\
\text { granulomas and Langham's giant } \\
\text { cells were seen. Acid-fast staining } \\
\text { showed the existence of numerous } \\
\text { AFB. TB PCR was positive for } \\
\text { MTB. The same was grown after } \\
40 \text { days in LJ medium. }\end{array}$ \\
\hline 30 & 2008 & Gupta et al. & Lung India & $\begin{array}{l}\text { Tuberculosis of spleen } \\
\text { presenting with pyrexia } \\
\text { of Unknown origin in a } \\
\text { non-immunocompromised } \\
\text { woman }\end{array}$ & $\begin{array}{l}\text { 49/F with fever of unknown } \\
\text { origin. Had tender } \\
\text { splenomegaly. CT revealed } \\
\text { an enlarged spleen with } \\
\text { multiple small focal } \\
\text { hypodense lesions } \\
\text { suggestive of abscesses. }\end{array}$ & $\begin{array}{l}\text { CT-guided biopsy from the splenic } \\
\text { lesions revealed epithelioid cells } \\
\text { granuloma with central necrosis } \\
\text { along with Langham's giant cells. } \\
\text { Culture of the specimen on LJ } \\
\text { medium isolated MTB. }\end{array}$ \\
\hline 31 & 2004 & Sharma et al. & $\begin{array}{l}\text { Indian Journal of Chest } \\
\text { Diseases and Allied } \\
\text { Sciences }\end{array}$ & $\begin{array}{l}\text { Tuberculous abscess of } \\
\text { the abdominal wall and } \\
\text { multiple splenic } \\
\text { abscesses in an } \\
\text { immunocompetent } \\
\text { patient }\end{array}$ & $\begin{array}{l}38 / \mathrm{M} \text { presented with a } \\
\text { well-defined abscess in the } \\
\text { abdominal wall. Spleen was } \\
\text { found to be enlarged, with } \\
\text { multiple small focal } \\
\text { hypodense lesions, } \\
\text { suggestive of abscesses }\end{array}$ & $\begin{array}{l}\text { CT guided FNA from the splenic } \\
\text { lesions showed epithelioid cell } \\
\text { granulomas in a necrotic background. } \\
\text { However, ZN stain revealed AFB in } \\
\text { the aspirate from abdominal wall } \\
\text { abscess which was later on confirmed } \\
\text { by mycobacterial culture. }\end{array}$ \\
\hline
\end{tabular}


Table 2. Summary of the diagnostic modalities in splenic tuberculosis.

\begin{tabular}{|c|c|c|c|c|}
\hline Article no. from Table 1 & AFB/ZN smear & CB-NAAT/PCR & MTB culture & Histopathology \\
\hline 1 & - & - & - & + \\
\hline 2 & + & + & - & - \\
\hline 5 & - & - & - & Cytology \\
\hline 6 & Negative & + & - & - \\
\hline 7 & + & - & + & - \\
\hline 8 & + & + & - & + \\
\hline 9 & - & - & - & + \\
\hline 10 & - & - & - & + \\
\hline 12 & - & - & - & + \\
\hline 15 & - & - & - & + \\
\hline 17 & + & - & - & - \\
\hline 18 & - & - & - & + \\
\hline $19 *$ & Negative & Negative & - & Inconclusive \\
\hline 20 & + & - & - & + \\
\hline 21 & Inadequate sample & Inadequate sample & - & + \\
\hline 24 & + & Inadequate sample & Inadequate sample & + \\
\hline 25 & Negative & + & - & + \\
\hline 26 & - & - & - & + \\
\hline 27 & + & - & + & - \\
\hline 28. $1^{\text {st }}$ Case & + & - & 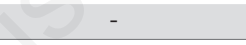 & - \\
\hline 28. $2^{\text {nd }}$ Case & - & - & $y$ & + \\
\hline 29 & + & 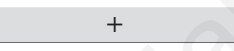 & + & + \\
\hline 30 & - & - & + & + \\
\hline 31 & - & - & - & + \\
\hline
\end{tabular}

Table 3. Summary of articles where splenic intervention was not done.

\begin{tabular}{|c|c|c|c|c|c|}
\hline Article no. from Table 1 & Site & $\mathrm{AFB} / \mathrm{ZN}$ smear & CB-NAAT/PCR & MTB culture & HPE \\
\hline 3 & Skin & - & + & - & - \\
\hline 4 & Liver & Neg & Neg & - & + \\
\hline 11 & Liver & - & - & - & + \\
\hline 13 & Skin & - & - & - & + \\
\hline 14 & Fistulous tract & Neg & Neg & - & + \\
\hline 16 & $\begin{array}{l}\text { Pleural fluid } \\
\text { Bone marrow }\end{array}$ & $\begin{array}{l}- \\
-\end{array}$ & $\begin{array}{l}+ \\
-\end{array}$ & $\begin{array}{l}- \\
+\end{array}$ & $\begin{array}{l}- \\
-\end{array}$ \\
\hline 22 & Liver & Neg & Neg & Neg & + \\
\hline $23^{*}$ & Ascitic fluid & - & - & - & - \\
\hline 31 & Abdominal wall abscess & + & - & + & - \\
\hline
\end{tabular}

\section{References}

1. Sharma SK, Mohan A. Extrapulmonary tuberculosis. Indian J Med Res 2004;38.

2. Paris S, Weiss SM, Ayers WH, et al. Splenic abscess. Am Surg 1994;60:358-61.

3. Sethi J, Shrivastava A, Gupta KL. Fever of unknown origin due to primary tubercular splenic abscess in a lowincome/middle-income country. BMJ Case Rep 2018; pii: bcr2018-225990. doi: 10.1136/bcr-2018-225990.
4. Mitra S, Mitra M, Sahoo S, et al. Tubercular splenic abscess: Two case reports with review of literature. J Assoc Chest Physicians 2015;3:69.

5. Divyashree S, Gupta N. Splenic abscess in immunocompetent patients managed primarily without splenectomy: a series of 7 cases. Perm J 2017;21:16-139. doi: 10.7812/TPP/16-139.

6. Dixit R, Arya MK, Panjabi M, et al. Clinical profile of patients having splenic involvement in tuberculosis. Indian $\mathrm{J}$ Tuberc 2010;57:25-30.

7. Chien K, Seemangal J, Batt J, et al. Abdominal tuberculosis: a 
descriptive case series of the experience in a Canadian tuberculosis clinic. Int J Tuberc Lung Dis 2018;22:681-5.

8. Karlo CA, Stolzmann P, Do RK, et al. Computed tomography of the spleen: how to interpret the hypodense lesion. Insights Imaging 2013;4:65-76.

9. Lim J, Yu JS, Hong SW, et al. A case of mass-forming splenic tuberculosis: MRI findings with emphasis of diffusionweighted imaging characteristics. J Korean Med Sci 2011;26:457-60
10. Mok Y, Tan TY, Tay TR, et al. Do we need transbronchial lung biopsy if we have bronchoalveolar lavage Xpert MTB/RIF? Int J Tuberc Lung Dis 2016;20:619-24. doi: 10.5588/ijtld.15.0463.

11. Gowda NC, Ray A, Soneja M, et al. Evaluation of Xpert ${ }^{\circledR}$ Mycobacterium tuberculosis/rifampin in sputum-smear negative and sputum-scarce patients with pulmonary tuberculosis using bronchoalveolar lavage fluid. Lung India 2018;35: 295-300 